\title{
RESIDUAL EFFECT OF ORGANIC MANURE AND RECOMMENDED NPK FERTILIZER ON YIELD AND BULB PERFORMANCE OF ONION (ALLIUM CEPA L.) AS SECOND CROP UNDER GREENHOUSE CONDITIONS
}

\author{
YOLDAS, F. $.^{*}-$ CEYLAN, ${ }^{1}{ }^{1}-$ MORDOGAN, N. ${ }^{2}$ \\ ${ }^{I}$ Department of Organic Production, Ödemis Vocational Training High School, Ege University \\ 35750 İzmir, Turkey \\ ${ }^{2}$ Department of Soil Science and Plant Nutrition, Faculty of Agriculture, Ege University \\ 35100 İmir, Turkey \\ Corresponding author \\ e-mail: funda.yoldas@ege.edu.tr; phone: +90-542-322-5385; fax: +90-232-544-4356 \\ (Received 28 $8^{\text {th }}$ Aug 2019; accepted $25^{\text {th }}$ Nov 2019)
}

\begin{abstract}
This study was conducted to determine the residual effects of chicken manure on the yield and yield performance of eight onion varieties as second crops after lettuce under greenhouse condition. 14-16, Burgaz, Karbeyaz1, Naz, NWG, Perwana, Seyhan, Şampiyon varieties and also four different doses of chicken manure at the rates of $0,20,40,60 \mathrm{tha}^{-1}$ with the recommended dose of NPK were used. A nonfertilized parcel was used as control. The experiment was laid out in split plot design and replicated three times. Yield and yield components were investigated. According to the results residual effect of chicken manure and onion varieties as second crop significantly affected the yield and bulb production in the greenhouse condition. The application of chicken manure significantly improved yield, bulb weight, bulb height, number of shoot tip, number of dried leaf compared to control. Highest yields $\left(72.99 \mathrm{t} \mathrm{ha}^{-1}\right)$ were obtained in the parcels where the chicken manure was applied at a rate of $20 \mathrm{tha}^{-1}$. The onion cultivar Burgaz was more responsive to the chicken manure compared to other onion cultivars. The best yield was shown of Burgaz cultivar and the $20 \mathrm{t} \mathrm{ha}^{-1}$ chicken manure treatments by the interaction. As a result, this method is the most suitable for onion production.
\end{abstract}

Keywords: residual effect, organic manure, NPK, second crop, greenhouse, onion growth characters, macro-micro elements

\section{Introduction}

Onions are members of the Allium genus of flowering plants that also includes garlic, shallots, leeks and chives. Onion is rich in several phytonutrients that are recognized as important elements of the Mediterranean diet but it has received attention also for its biological properties and potential application in the treatment and prevention of a number of diseases (Lim, 2015; Marrelli et al., 2019). Onion (Allium cepa L.) is also a vegetable that is widely consumed due to its flavoring and health-promoting properties. Onions have many possible health benefits including reducing the risk of obesity, heart disease, and cancer. Onion bulb is a rich source of minerals like phosphorus, calcium, magnesium, iron, manganese and carbohydrates. It also contains protein, Vitamin $\mathrm{C}$, Vitamin B6 and antioxidants and is rich in sulphur amino acids (Ware, 2017). Moreover, a variety of secondary metabolites have been identified in this species, such as flavonoids (particularly flavonols and anthocyanin), phytosterols and saponins (Griffiths et al., 2002; Marrelli et al., 2019).

According to the statistics, Turkey's bulb onion production is 1930695 tons over a 53 000-hectare area (Anonymous, 2018). 
Healthy life and environmental consciousness are important today. In this case it caused to increase on naturel feeding. With the development and perfection of market economy, agriculture and rural economy is coming to a new stage and the lives of people working in this sector, since there is now a demand for production of safe and high quality agricultural products (Liu et al., 2011). The reasonable use of organic manure can improve soil fertility and microbial content, decrease soil nitrogen accumulation and leaching loss, increase yield and quality, and improve human ecological environment (Yi et al., 2004; Gao et al., 2005; Liu et al., 2011).

Pollution with chemical fertilizers arose as an aim of health care, thus attempts were made for solving problems of chemical fertilization, and the organic farming technique represents a move towards an alternative system of agriculture (Abd-Allah et al., 2001; Yassen and Khalid, 2009). Organic material, such as sheep and chicken manure, improves soil physical properties (structure and aggregation) and soil chemical properties (decrease soil $\mathrm{pH}$, increase cation exchange capacity and enhance most nutrients) that are important for plant growth (Snyman et al., 1998; Yassen and Khalid, 2009). Using of chemical matter was decreased and naturel productions get importance. But soil fertility is important in this case. Organic matter improves soil's physical, chemical, biological properties and is also effect the availability of nutrient. But high level organic material in soils especially in dry conditions may be caused unable effects and also it can create organo-mineral complex and it reduced the availability of some mineral (Sezen, 1995). Animal fertilizers are major source of organic matter for soil.

Organic fertilizer has been widely used as alternative fertilizers for organically grown fields (Jongtae, 2010). Organic manures can serve as alternative to mineral fertilizers as reported by Naeem et al. (2006) for improving soil structure (Dauda et al., 2008) and microbial biomass (Suresh et al., 2004).

Organic material, such as farmyard manure improves soil physico-chemical properties that are important for plant growth (Snyman et al., 1998). Decomposition of materials would provide additional nutrients to the growing medium which may lead to higher uptake of nutrient by the crop and subsequently high yield. Besides, organic manures have positive effect on root growth by improving the root rhizosphere conditions (structure, humidity, etc.) and also plant growth is encouraged by increasing the population of microorganisms (Shaheen et al., 2007; Kidanu, 2017).

Comparisons of conventional and organic farms matched by soil type indicated that organic practices improved soil fertility (Liebig and Doran, 1999). This included a 22\% increase in organic matter, $20 \%$ more total N, lower bulk density and higher water holding capacity.

Organic farming provides several benefits to the growers. It reduces production cost and it is an environmentally friendly method of cultivation. Addition of organic fertilizers improves soil structure and enhances activities of useful soil organisms (Snyman et al., 1998; Ramesh et al., 2005). Agricultural commodities resulted from organic cultivation are good for human health. however, organic manures alone cannot provide sufficient quantities of required nutrients and are unable to give economic yield and hence, it is vital to find appropriate combinations of inorganic and organic manure to obtain financially viable yield of crops. Jayathilake et al. (2006) reported that integrated use of bio-fertilizer, organic manure and chemical fertilizers resulted in onion yield increase in comparison with the exclusive application of chemical fertilizers (Kidanu, 2017).

Organic manure increases the nutrient status of a soil which leads to increase in onion yield (Akoun, 2004; Kidanu, 2017). 
Boyhan and Hill (2008) found that fertilizer requirements were higher with organic fertilizer sources compared with conventional fertilizers presumably because nutrients were less available in organic compounds due to slow mineralization rates.

Work has been done to predict the availability of plant nutrients from organic sources over time. Whitmore (2007), for example, found that $40 \%$ of the total $\mathrm{N}$ from composted chicken manure was available in the first year, with the remainder available in subsequent years at a rate of $6 \%$ to $12 \%$ per year.

A number of studies have been conducted evaluating the organic production of onions (Piazza et al., 2003; Sharma et al., 2004; Gonçalves and Sousa e Silva, 2004; Beek, 2005; Russo, 2005; Boyhan et al., 2006; Boyhan and Hill, 2008). These studies have evaluated fertility, insect control, weed control, transplant production, various cropping systems, and varieties (George et al., 2010; Ewais et al., 2010). Many researchers reported that soil application of chicken manure increased yield and yield criteria of onion (Shaheen et al., 2007; Dina et al., 2010; El-Shatanofy and Manar, 2011; Yoldas et al., 2011; Ali et al., 2018).

Onion shows significant response to organic and inorganic fertilizers (Nasreen and Hossain, 2000; Soleymani and Shahrajabian, 2012; Kidanu, 2017). Therefore, the usage of organic manures as alternative source of nitrogen would give better result in its growth and yield.

The objective of this study was to evaluate residual effect of organic manure and recommended NPK fertilizer on yield and bulb performance of onion (Allium cepa L.) as second crop under greenhouse condition.

\section{Materials and Methods}

The study was carried out in experimental area of the Ödemiş Vocational School, at the Ege University, in İzmir (38 $\left.16^{\circ} \mathrm{N}, 2^{\circ} 59^{\prime} \mathrm{E}\right)$, Turkey during the 2017 year. The experimental designs were split plot with three replications. Before sowing of lettuce, the chicken manure was applied to soil at the rates of $0-20-40-60 \mathrm{t} \mathrm{ha}^{-1}$ and also recommended dose of NPK (150:100:150 kg ha $\left.{ }^{-1}\right)$. Mineral fertilizers have applied as $\mathrm{NH}_{4} \mathrm{NO}_{3}$ and $\mathrm{K}_{2} \mathrm{SO}_{4}$ formulated product. Five different treatments with control and three replications were conducted in 15 plots. In the control treatment neither organic nor mineral fertilization had been done. Lolla Rossa lettuce variety was sown and harvested at the end of vegetation. After harvesting the lettuce plant, onion varieties were sown in order to determine the residual effect of chicken manure and chemical fertilizer in greenhouse conditions. No nutrient addition was made for onion. In this study, during the growth period, weeds were removed by hand hoeing and irrigation was done on a regular basis. The spraying procedures and plant protection were regularly applied throughout the production.

Eight onion varieties called 14-16, Burgaz, Karbeyaz1, Naz, NWG, Pewana, Seyhan, Şampiyon were used. They are long day / storage. Their fruits are a round, brown-shelled, widely known and kept Variety on the market due to its uniform nature. Due to their very strong root structure. Resistant to pink root rot and Fusarium. Allium cepa L. was planted in each plot with $30 \mathrm{~cm}$ between rows and $15 \mathrm{~cm}$ within the rows. Total plot length is $11.5 \mathrm{~m}$ and plot width is $6.2 \mathrm{~m}$.

The composition of chicken manure that residual effect investigated was analyzed according to Kacar (1995) and is presented in Table 1. 
Soil samples $(0-20 \mathrm{~cm})$ were collected from the individual experimental plots (15 samples) at the beginning of onion vegetation. The soil sample was air dried, ground, and passed through $2 \mathrm{~mm}$ sieve for the determination of chemical parameters. $\mathrm{pH}$ (Jackson, 1967), total soluble salt (Anonymous, 1951), $\mathrm{CaCO}_{3}$ (Kacar, 1995), organic matter content (Reuterberg and Kremkurs, 1951) were determined in the soil. Total N was also analyzed according to Bremner (1965), the available $\mathrm{K}^{+}$, was determined after extracting with $1 \mathrm{~N} \mathrm{NH}_{4} \mathrm{OAc}$ by flame photometer (Atalay et al., 1986) and available $\mathrm{P}$ was measured by colorimeter (Olsen et al., 1954).

Table 1. Some properties of chicken manure

\begin{tabular}{c|c|c|c}
\hline $\mathbf{p H}$ & 8.55 & $\mathbf{C} / \mathbf{N}$ & 12.1 \\
Total Salt (ms/cm) & 2.47 & $\mathbf{P}(\boldsymbol{\%})$ & 0.70 \\
Ash 550 $\mathbf{~} \mathbf{C}(\%)^{\mathbf{\%}}$ & 79 & $\mathbf{K}(\boldsymbol{\%})$ & 1.02 \\
Organic Matter (\%) & 19.8 & $\mathbf{C a}(\boldsymbol{\%})$ & 1.37 \\
Organic Carbon (\%) & 11.51 & $\mathbf{M g}(\mathbf{p p m})$ & 3729 \\
Total N (\%) & 0.95 & $\mathbf{N a}(\mathbf{p p m})$ & 1248 \\
\hline
\end{tabular}

At the end of the vegetation, onions were harvested. Average bulb head weight, bulb height, bulb width and flesh thickness, number of storage leaf, number of shoot tip, and number of dried leaf were determined as growth and yield parameters.

Ten randomly selected plants were harvested from each plot (avoiding side effect) to record the data on data set for all characters. Bulb length and diameter refers to the height of the bulb and the average width at the widest point in the middle portion of the mature bulb measured using vernier caliper. Average bulb weight computed by weighing ten bulbs together and calculating the average. Total bulb yield was computed based on the weight of matured bulbs yield per plot and converted in to hectare base and expressed in tones. Marketable bulb yield was determined after discarding bulbs smaller than $3 \mathrm{~cm}$ in diameter, splitted, thick necked, rotten and discolored. Split bulbs percentage was determined by counting the number of split bulbs per plot and expressed in percentage in reference to total number of normal bulbs per plot.

The collected data on various parameters were statistically analyzed. Analysis of variance was computed and LSD was used to compare means. Trial statistical evaluation result of data was done using software package TARIST (Açikgöz et al., 1993).

\section{Results and Discussion}

\section{Soil properties}

Some chemical properties and macro-micro nutrient contents of greenhouse trial soil before onion sowing are presented in Tables 2 and 3. $\mathrm{pH}$, organic matter, lime, $\mathrm{P}, \mathrm{K}, \mathrm{Ca}$, $\mathrm{Mg}, \mathrm{Na}, \mathrm{Fe}, \mathrm{Zn}, \mathrm{Mn}, \mathrm{Cu}$ values in the soil did not show any statistical difference between applications at the beginning of vegetation. On the contrary, total $\mathrm{N}$ content of the soil was significantly affected by the applications. The highest values $(0.084 \%)$ were analyzed in the parcels which the chicken manure was applied as $40 \mathrm{t} \mathrm{ha}^{-1}$.

Before onion sowing, greenhouse soil properties are neutral (6.6-7.3) except the parcels which the chicken manure was applied as $20 \mathrm{t} \mathrm{ha}^{-1}$. However, in this application, soils showed slightly alkaline properties (7.4-7.8). Low humus (1.33-1.61\%) and lime $(0-2.5 \%)$ poor. When the productivity status of the soil is investigated, $\mathrm{N}$ is moderate 
(0.05-0.1\%); K (< $150 \mathrm{ppm}), \mathrm{Ca}(715-1430 \mathrm{ppm})$ poor; rich in $\mathrm{P}(3.26 \mathrm{ppm}) ; \mathrm{Mg}(>$ $114 \mathrm{ppm})$ is good; $\mathrm{Fe}(>4.5 \mathrm{ppm}), \mathrm{Zn}(>1 \mathrm{ppm}), \mathrm{Mn}(>1 \mathrm{ppm})$ and $\mathrm{Cu}(>0.2 \mathrm{ppm})$ is determined to be sufficient according to Güneş et al. (2000).

Table 2. Some chemical properties of greenhouse trial soils at the beginning of onion vegetation

\begin{tabular}{c|c|c|c}
\hline Treatment & pH & O.M. (\%) & CaCO3 (\%) \\
\hline $\mathbf{0}$ & 7.24 & 1.57 & 0.92 \\
NPK & 7.25 & 1.47 & 0.43 \\
$\mathbf{2 0}$ t ha $^{-1}$ & 7.44 & 1.61 & 0.86 \\
$\mathbf{4 0}$ t ha$^{-1}$ & 7.29 & 1.33 & 0.42 \\
$\mathbf{6 0}$ t ha $^{-1}$ & 7.15 & 1.47 & 0.36 \\
LSD & n.s. & n.s. & n.s. \\
\hline
\end{tabular}

**: $\mathrm{p}<0.01 ; *: \mathrm{p}<0.05 ;$ n.s.: not significant

Table 3. Macro-micro nutrient contents of greenhouse trial soils at the beginning of vegetation

\begin{tabular}{|c|c|c|c|c|c|}
\hline \multirow{2}{*}{ Treatment } & Total N & $\mathbf{P}$ & $\mathbf{K}$ & $\mathbf{C a}$ & Mg \\
\hline & $(\%)$ & $\left(\mathrm{mg} \mathrm{kg}^{-1}\right)$ & $\left(\mathrm{mg} \mathrm{kg}^{-1}\right)$ & $\left(\mathrm{mg} \mathrm{kg}^{-1}\right)$ & $\left(\mathrm{mg} \mathrm{kg}^{-1}\right)$ \\
\hline $\mathbf{0}$ & $0.056 \mathrm{c}$ & 51.30 & 104.4 & 1386 & 323 \\
\hline NPK & $0.078 \mathrm{ab}$ & 56.35 & 133.5 & 1023 & 305 \\
\hline $20 \mathrm{tha}^{-1}$ & $0.067 \mathrm{bc}$ & 60.51 & 133.4 & 1254 & 303 \\
\hline $40 \mathrm{t} \mathrm{ha}^{-1}$ & $0.084 \mathrm{a}$ & 63.45 & 136.4 & 1188 & 318 \\
\hline $60 \mathrm{t} \mathrm{ha}^{-1}$ & $0.081 \mathrm{ab}$ & 62.05 & 146.5 & 1221 & 308 \\
\hline LSD & $0.015^{* *}$ & n.s. & n.s & n.s & n.s \\
\hline \multirow{2}{*}{ Treatment } & $\mathrm{Na}$ & $\mathrm{Fe}$ & Zn & Mn & $\mathbf{C u}$ \\
\hline & $\left(\mathrm{mg} \mathrm{kg}^{-1}\right)$ & $\left(\mathrm{mg} \mathrm{kg}^{-1}\right)$ & $\left(\mathrm{mg} \mathrm{kg}^{-1}\right)$ & $\left(\mathrm{mg} \mathrm{kg}^{-1}\right)$ & $\left(\mathrm{mg} \mathrm{kg}^{-1}\right)$ \\
\hline$\overline{\mathbf{0}}$ & 35.3 & 29.49 & 5.30 & 14.57 & 2.92 \\
\hline NPK & 26.0 & 23.16 & 4.40 & 12.93 & 2.73 \\
\hline $20 \mathrm{tha}^{-1}$ & 25.8 & 23.51 & 4.71 & 13.45 & 2.65 \\
\hline $40 \mathrm{t} \mathrm{ha}^{-1}$ & 32.0 & 27.13 & 4.72 & 13.91 & 2.78 \\
\hline $60 \mathrm{tha}^{-1}$ & 57.7 & 23.58 & 5.33 & 14.31 & 2.83 \\
\hline LSD & n.s & n.s & n.s & n.s & n.s \\
\hline
\end{tabular}

**: $\mathrm{p}<0.01 ; *: \mathrm{p}<0.05 ;$ n.s.: not significant

\section{Onion yield and yield characteristics}

Residue effect of chicken manure on yield and some quality criteria of onion as second crop after the lettuce production are given in Table 4.

\section{Yield}

In the greenhouse condition, the results showed significant differences in yield amongst treatments $(\mathrm{p}<0.01)$ (Table 4). Highest yields $\left(72.99 \mathrm{t} \mathrm{ha}^{-1}\right)$ were obtained in the parcels which the chicken manure was applied as $20 \mathrm{t} \mathrm{ha}^{-1}$. This application increased yield by $8 \%$ compared to the control plots. But there is no statistically significant difference in yield between mineral fertilizer and $20 \mathrm{t} \mathrm{ha}^{-1}$ of chicken manure application. Similarly, Rumpel (1998), Sharma et al. (2003), Yoldas et al. (2011), Indira and Singh (2014) and Zewde et al. (2018) found that animal manure applications increased onion yield. 
Many researchers also reported similar results that soil application of chicken manure increased yield and yield criteria of onion (Shaheen et al., 2007; Dina et al., 2010; ElShatanofy and Manar, 2011; Yoldas et al., 2011; Ali et al., 2018).

Organic manures activate many species of living organisms which release phytohormones and may stimulate the plant growth and absorption of nutrients (Arisha et al., 2003). Organic manures improved the water holding capacity of soil and provide nutrients for a long duration due to less leaching of nutrients and increase efficiency (Carol et al., 1999). Mahala et al. (2018) reported that the increased yield and yield parameters with poultry manure might be because of rapid availability and utilization of nitrogen for various internal plant processes for carbohydrates production. Later on these carbohydrates may undergo hydrolysis and get converted into reproductive sugars which ultimately helped in increasing yield.

Table 4. Residue effect of chicken manure on yield and some quality criteria of onion as second crop in the greenhouse condition

\begin{tabular}{|c|c|c|c|c|c|c|c|}
\hline \multirow{2}{*}{ Treatment } & Yield & Bulb weight & Bulb width & Bulb height & $\begin{array}{l}\text { Number of } \\
\text { stored leaf }\end{array}$ & $\begin{array}{c}\text { Number of } \\
\text { shoot tip }\end{array}$ & $\begin{array}{l}\text { Number of } \\
\text { dried leaf }\end{array}$ \\
\hline & $\left(\mathrm{t} \mathrm{ha}^{-1}\right)$ & $\left(\mathrm{g} \mathrm{no}^{-1}\right)$ & $(\mathrm{cm})$ & $(\mathbf{c m})$ & (no) & (no) & (no) \\
\hline $\mathbf{0}$ & $67.54 \mathrm{bc}$ & $202.641 \mathrm{bc}$ & $7.265 \mathrm{ab}$ & $7.491 \mathrm{a}$ & $2.188 \mathrm{c}$ & $1.569 \mathrm{~b}$ & $6.830 \mathrm{c}$ \\
\hline NPK & $71.87 \mathrm{ab}$ & $215.638 \mathrm{ab}$ & $7.377 \mathrm{ab}$ & $7.513 \mathrm{a}$ & $2.278 \mathrm{~b}$ & $1.722 \mathrm{a}$ & $7.111 \mathrm{~b}$ \\
\hline 20 tha $^{-1}$ & $72.99 \mathrm{a}$ & $219.006 \mathrm{a}$ & $7.494 \mathrm{a}$ & $7.329 \mathrm{~b}$ & $2.313 \mathrm{~b}$ & $1.730 \mathrm{a}$ & $7.395 \mathrm{a}$ \\
\hline $40 \mathrm{t} \mathrm{ha}^{-1}$ & $66.02 \mathrm{c}$ & $198.068 \mathrm{c}$ & $7.188 \mathrm{~b}$ & $7.368 \mathrm{~b}$ & $2.430 \mathrm{a}$ & $1.666 \mathrm{a}$ & $6.757 \mathrm{c}$ \\
\hline $60 \mathrm{t} \mathrm{ha}^{-1}$ & $66.91 \mathrm{c}$ & $200.735 \mathrm{c}$ & $7.396 \mathrm{ab}$ & $7.054 \mathrm{c}$ & $2.097 \mathrm{~d}$ & $1.694 \mathrm{a}$ & $6.742 \mathrm{c}$ \\
\hline LSD & $4.418 * *$ & $13.255^{* *}$ & $0.267 * *$ & $0.097 * *$ & $0.081 * *$ & $0.077 * *$ & $0.196^{* * *}$ \\
\hline
\end{tabular}

Similar results were found by Jongtae (2010). In that research, no significant yield difference was found between chemical fertilization and organic fertilization with mulch.

Velmurugan and Swarnam (2017) explained similar to the results that rice grain yield was significantly affected by the residual effect of manures and inorganic fertilizer to okra.

Different our results, Abdelrezzag (2002) reported that chicken manure tended to reduce onion yield for all levels in comperation with fertilizer and control. The usage of organic manures as alternative source of nitrogen would give better result in its growth and yield (Nasreen and Hossain, 2000; Kidanu, 2017).

In the study, the highest yield was observed Burgaz variety $(\mathrm{p}<0.01)$ (Table 5). Highest yield after Burgaz obtained with Şampiyon variety. The differences in yield among varieties can be caused by differences in genetic characteristics of varieties (Khan et al., 2011; Abou-El-Hassan et al., 2018).

\section{Bulb weight}

Treatments, variety and the interaction between onion cultivars and treatment affected bulb weight of onion significantly $(\mathrm{p}<0.01)$. Highest values $(219.006 \mathrm{~g})$ were obtained in the parcels which the chicken manure was applied as $20 \mathrm{t} \mathrm{ha}^{-1}$ in the greenhouse (Table 4). This application increased weight of onion by $8 \%$ compared to the control plots. But there was no statistically significant difference in bulb weight between mineral fertilizer and $20 \mathrm{t} \mathrm{ha}^{-1}$ of chicken manure application. Similarly, Yohannes et al. (2013) 
reported that farmyard manure and nitrogen fertilizer increased bulb weight. Organic fertilizers provide nutrients to the plants by decomposing and increase growth and yield. Manures improved the soil structure, fertile and availability of nutrient to the plant. Better nutrition of the plant; increase the cell division of plant tissues and the rate of photosynthesis. This is reflected in product growth and the bulb weight (Ewais et al., 2010).

Bulb weights of Burgaz variety (316.283 g) were higher than the others onion variety significantly (Table 5).

The interaction between onion cultivars and treatment for bulb weight was found statistically significant The highest bulb weights was obtained in Burgaz variety with $20 \mathrm{tha}^{-1}$ as $339.267 \mathrm{~g}$ in greenhouse condition.

Table 5. Effect of variety on yield and same quality criteria of onion as second crop depending on residue effect of chicken manure in greenhouse condition

\begin{tabular}{|c|c|c|c|c|c|c|c|}
\hline \multirow[t]{2}{*}{ Variety } & Yield & Bulb weight & Bulb width & Bulb height & \begin{tabular}{|l|} 
Number of \\
storage leaf
\end{tabular} & $\begin{array}{c}\text { Number of } \\
\text { shoot tip }\end{array}$ & $\begin{array}{c}\text { Number of } \\
\text { dried leaf }\end{array}$ \\
\hline & $(\mathrm{t}$ ha-1) & $\left(\mathrm{g} \mathrm{no}^{-1}\right)$ & $(\mathrm{cm})$ & (cm) & (no) & (no) & (no) \\
\hline $14-16$ & $60.23 \mathrm{~d}$ & $180.697 \mathrm{~d}$ & $7.115 \mathrm{~cd}$ & $7.089 \mathrm{~d}$ & $2.189 \mathrm{~d}$ & $1.911 \mathrm{~b}$ & $6.167 \mathrm{~d}$ \\
\hline Burgaz & $105.40 \mathrm{a}$ & $316.283 \mathrm{a}$ & $8.745 \mathrm{a}$ & $8.648 \mathrm{a}$ & $3.101 \mathrm{a}$ & $2.611 \mathrm{a}$ & $8.289 \mathrm{~b}$ \\
\hline Kar Beyazı & $67.69 \mathrm{c}$ & $203.087 \mathrm{c}$ & $7.163 \mathrm{~cd}$ & $8.029 \mathrm{~b}$ & $2.599 \mathrm{c}$ & $1.611 \mathrm{c}$ & $8.971 \mathrm{a}$ \\
\hline $\mathrm{Naz}$ & $60.25 \mathrm{~d}$ & $180.761 \mathrm{~d}$ & $7.334 \mathrm{c}$ & $6.667 \mathrm{e}$ & $1.521 \mathrm{e}$ & $1.489 \mathrm{~d}$ & $5.456 \mathrm{f}$ \\
\hline NWG & $61.43 \mathrm{~d}$ & $184.309 \mathrm{~d}$ & $6.589 \mathrm{e}$ & $7.527 \mathrm{c}$ & $1.545 \mathrm{e}$ & $1.577 \mathrm{c}$ & $6.389 \mathrm{c}$ \\
\hline Perwana & $50.73 \mathrm{e}$ & $152.195 \mathrm{e}$ & $6.995 \mathrm{de}$ & $5.752 \mathrm{~g}$ & $2.199 \mathrm{~d}$ & $1.600 \mathrm{c}$ & $5.567 \mathrm{f}$ \\
\hline Seyhan & $49.51 \mathrm{e}$ & $148.535 \mathrm{e}$ & $6.382 \mathrm{f}$ & $6.276 \mathrm{f}$ & $2.156 \mathrm{~d}$ & $1.611 \mathrm{c}$ & $5.911 \mathrm{e}$ \\
\hline Şampiyon & $97.30 \mathrm{~b}$ & $291.919 \mathrm{~b}$ & $8.160 \mathrm{~b}$ & $8.820 \mathrm{a}$ & $2.778 \mathrm{~b}$ & $1.000 \mathrm{e}$ & $8.989 \mathrm{a}$ \\
\hline LSD & $4.28 * *$ & $12.841 * *$ & $0.228 * *$ & $0.245^{* *}$ & $0.094 * *$ & $0.070 * *$ & $0.189 * *$ \\
\hline
\end{tabular}

**: $\mathrm{p}<0.01 ; *: \mathrm{p}<0.05 ;$ n.s.: not significant

\section{Bulb width}

The residual effect of chicken manure and mineral NPK applications on onion bulb width was found significant (Table 4). Contrarily, Yohannes et al. (2013) and Mekonnen et al. (2017) reported that farmyard manure did not affect bulb width of onion in their work.

The highest bulb width $(8.745 \mathrm{~cm})$ was observed Burgaz variety $(\mathrm{p}<0.01)$ followed by the bulb width $(8.160 \mathrm{~cm})$ in Şampiyon variety (Table 5). The interaction between onion cultivars and treatment for bulb width was statistically important. Maximum bulb width was obtained in Burgaz variety with $20 \mathrm{t} \mathrm{ha}^{-1}$ as $8.897 \mathrm{~cm}$.

\section{Bulb height}

Onion bulb height was significantly $(\mathrm{p}<0.01)$ affected by the residual effect of chicken manure and mineral NPK applications (Table 4). The highest value $(7.513 \mathrm{~cm})$ was determined in mineral NPK application and followed bulb height $(6.49 \mathrm{~cm})$ by the application of control. There is contrast with Yohannes et al. (2013) who reported that application of FYM at a rate of 45 ton $^{-1}{ }^{-1}$ gave the highest mean bulb diameter $(5.99 \mathrm{~cm})$. Consistent with their results Metwally and Bary (1999) suggested that the poultry manure improve the bulb growth by enhancing the soil properties and overcome the leaching of 
nutrients from the root zone. As different Mekonnen et al. (2017) reported that organic manure did not significantly influence bulb length.

In the study, bulb height of Şampiyon variety $(8.820 \mathrm{~cm})$ was reported higher than other varieties $(\mathrm{p}<0.01)$ (Table 5). The interaction between onion cultivars and treatment for bulb height was also found significant. Maximum bulb height was obtained in Şampiyon variety with the mineral fertilizer NPK as $9.857 \mathrm{~cm}$.

The differences in the responses to the applications of onion varieties may be genetic variation and also depending on the adoptability of variety in specific environment (Shah et al., 2012; Ali et al., 2018).

\section{Number of storage leaf}

According to statistical analyzes, number of storage leaf was affected from the treatments. But these characteristics have changed significantly in relation to the varieties (Tables 4 and 5). Highest value was obtained in Burgaz variety (3.101) followed by Şampiyon variety (2.778) (Table 5). There was statistically significant difference between Burgaz and Şampiyon variety. The interaction between onion cultivars and treatment had a significant effect on the number of storage leaf $(p<0.01)$. The number of storage leaf was highest in the application of $40 \mathrm{t} \mathrm{ha}^{-1}$ and Burgaz variety.

\section{Number of shoot tip}

The results presented in Tables 4 and 5 showed that treatment and onion variety had significantly affected number of shoot tip of onion, where the interaction had also significantly affected. The highest number of shoot tip (1.730) was observed with the application of chicken manure at the rate of $20 \mathrm{t} \mathrm{ha}^{-1}$ (Table 4). While the lowest numbers of shoot tip (1.569) was observed in control application. Among the onion variety highest number of shoot tip was recorded in variety Burgaz (2.611).

Maximum number of shoot tip was obtained in Burgaz variety with the $40 \mathrm{t} \mathrm{ha}^{-1}$ of chicken manure application.

\section{Number of dried leaf}

Treatments, variety and the interaction between onion cultivars and treatment affected number of dried leaf of onion significantly $(\mathrm{p}<0.01)$ (Tables 4 and 5). Highest value (7.395) was obtained in the parcels which the chicken manure was applied as $20 \mathrm{tha}^{-1}$ in the field. Number of dried leaf of Şampiyon variety (8.989) were higher than the others onion variety significantly (Table 5). The highest number of dried leaf was obtained in Karbeyazı variety with $20 \mathrm{tha}^{-1}$ as 10.220 .

\section{Conclusion}

As a conclusion it was found that residual effect of chicken manures recommended NPK fertilizer and onion varieties as second crop significantly affected the yield and bulb production in the greenhouse condition. Residual of chicken manure increased yield, bulb weight, bulb height, number of dry shell, number of shoots of onion varieties. The highest results were obtained especially with $20 \mathrm{t} \mathrm{ha}^{-1}$ of chicken manure application in the greenhouse condition. The onion varieties Burgaz gave more response to the organic manure as compare with other onion varieties in yield, bulb weight, bulb height, bulb width, number of storage leaf. The lowest amount of animal manure improved many 
examined parameters significantly but increasing the rate of using the chicken manure had negative effects.

In today's world, where healthy life and environmental consciousness is gaining importance, it should be aimed to increase the conscious use of natural organic fertilizers.

Acknowledgement. This research is a work supported by Scientific Research Project Commission of Ege University; Contact no: 2017/OMYO/001.

\section{REFERENCES}

[1] Abd-Allah, A. M., Adam, S. M., Abou-Hadid, A. F. (2001): Productivity of green cowpea in sandy soil as influenced by different organic manure rates and sources. - Egypt. J. Hort.Sci. 28(3): 331-340.

[2] Abdelrazzag, A. (2002): Effect of chicken manure, sheep manure and inorganic fertilizer on yield and nutrients uptake by onion. - Pakistan J. Biol. Sci. 5(3): 266-268.

[3] Abou-El-Hassan, S., Elmehrat, H. G., Ragab, A. A., Abo-Dahab, A. M. M. A. (2018): Growth, yield, bulb quality and storability of some onion cultivars response to compost, vermicompost and plant growth promoting Rhizobacteria. - Middle East J. Agric. Res. 7(2): 292-306.

[4] Açıgöz, N., Akka, M. E., Maghaddam, A., Özcan, K. (1993): Database dependent. Congress of International Practice of Computer, p: 133.

[5] Akoun, J. (2004): Effect of plant density and manure on the yield and yield components of the common onion (Allium cepa L.) variety nsukka red. - Nigerian Journal of Horticultural Science 9: 43-48.

[6] Ali, M., Khan, N., Khan, A., Ullah, R., Naeem, A., Khan, M. W., Khan, K., Farooq, S., Rauf, K. (2018): Organic manures effect on the bulb production of onion cultivars under semiarid condition. - Pure Appl. Biol. 7(3): 1161-1170.

[7] Anonymous. (1951): U.S. soil survey staff, soil survey manual. - U.S. Dept. Agr. Handbook 18, U.S. Govt. Printing Office, Washington DC, USA.

[8] Anonymous. (2018): Plant Production Statistics. - www.tuik.gov.tr.

[9] Arisha, H. M. E., Gad, A. A., Younes, S. E. (2003): Response of some pepper cultivars to organic and mineral nitrogen fertilizer under sandy soil conditions. - Zagazig J. Agr. Res. 30: 1875-1899.

[10] Atalay, I. Z., Kılınç, R., Anaç, D., Yokaş, İ. (1986): Gediz havzası rendzina topraklarının potasyum durumu ve bu topraklarda alınabilir potasyum miktarlarının tayininde kullanılacak yöntemler. - Bilgehan Matbaası, İzmir, s.25.

[11] Beek, M. A. (2005): Perspectives of organic onion production: The Dutch experience as an example for an emerging market economy as China. - Acta Hort. 688: 339-346.

[12] Boyhan, G. E., Hicks, R., Hill, C. R. (2006): Natural mulches are not very effective for weed control in onions. - HortTechnology 16: 523-526.

[13] Boyhan, G. E., Hill, C. R. (2008): Organic fertility sources for the production of short-day organic onion transplants. - Hort. Technology 18: 227-231.

[14] Boyhan, G. E., Hicks, R. J., Torrance, R. L., Riner, C. M., Hill, C. R. (2010): Evaluation of Poultry Litter and Organic Fertilizer Rate and Source for Production of Organic Shortday Onions. - Horttechnology 20(2): 304-307.

[15] Bremner, J. M. (1965): Total Nitrogen. - In: Black, C. A., Evans, D. D., White, J. L., Ensminger, L. E., Clark, F. E., Dinauer, R. C. (eds.) Methods of soil analysis. Part 2: Chemical and microbiological properties. Am. Soc. of Agron., Madison, Wisc. Agron Ser. 9: 1149-1237. 
[16] Carol, M., Tanya, C., Tamera, F. (1999): A manure resource guide for farmers and gardeners in Western Washington. - King Conservation District 935 Powell Ave SW Renton. WA 98055. pp 206.

[17] Dauda, S. N., Ajayi, F. A., Ndor, E. (2008): Growth and yield of water melon (Citrulluslanatus) as affected by poultry manure application. - Journal of Agriculture and Social Science 4: 121-124.

[18] Dina, M. S., Shafeek, M. R., Abdallah, M. M. F. (2010): Effect of different nitrogen sources and soil solarization on green onion productivity for exportation. - Annals of Agric. Sci., Cairo Univ. 55(1): 97-106.

[19] El-Shatanofy, Manar, M. E. (2011): Influence of organic manure and inorganic fertilizers on growth, yield and chemical contents of onion (Allium cepa, L.).- M.Sc. Thesis, Fac. of Agric. Alex. Univ.

[20] Ewais, M. A., Mahmoud, A. A., Khalil, A. A. (2010): Effect of nitrogen fertigation in comparison with soil application on onion production in sandy soils. - Alex J Agric Res 55(3): 75-83.

[21] Gao, X., Zhang, Z., Guo, S. (2005): Effects of combined top application of inorganic nitrogen and potassium on the yield and quality of overwintering tomato in greenhouse. Plant Nutrition and Fertilizer Science 11(3): 375-378.

[22] Gonçalves, P. A., de Souza, C. R., Sousa, E. S. (2004): Mineral and organic fertilization and onion thrips, Thripstabaci Lind. (Thysanoptera: Thripidae) population density. Ciencia Rural 34: 1255-1257.

[23] Griffiths, G., Trueman, L., Crowther, T., Thomas, B., Smith, B. (2002): Onions-A global benefit to health. - Phytother. Res. 16: 603-615. doi: 10.1002/ptr.1222.

[24] Guneş, A., Alpaslan Inal, M. (2000): Bitki besleme ve gübreleme. - Ankara Üniversitesi Ziraat Fak. Yayın No: 1514, s: 199.

[25] Indira, S., Singh, S. J. (2014): Effect of vermicompost and bio fertilizer on yield and quality of rabi onion (Allium cepa L) cv. puna red. - Agric. Sci. Digest. 34(2): 144-146.

[26] Jackson, M. L. (1967): Soil chemical analysis. - Prentice-Hall of India Pvt. Ltd., New Delhi.

[27] Jayathilake, P. K. S., Reddy, I. P., Srihari, D., Reddy, K. R. (2006): Productivity and soil fertility status as influenced integrated use of $\mathrm{N}$-fixing Bio fertilizers, organic manures and inorganic fertilizers in onion. - Journal of Agricultural Sciences 2(1): 46-58.

[28] Jongtae, L. (2010): Effect of application methods of organic fertilizer on growth, soil chemical properties and microbial densities in organic bulb onion production. - Scientia Horticulturae 124: 299-305.

[29] Kacar, B. (1995): Toprak analizleri: Bitki ve toprağın kimyasal analizleri III. - Ankara Üni., Zir. Fak., Eğitim Araş. ve Geliştirme Vakfi Yayınları: 81-86.

[30] Khan, I. M., Hassan, G., Khan, I., Marwat, K. B. (2011): Testing of herbicides at various doses on the growth stages of wild onion grown in pots. - Sarhad J Agric 27(1): 85-91.

[31] Kidanu, Y. G. (2017): Effect of Integrated Nutrient Management on Growth, Bulb Yield and Storability of Onion (Allium Cepa L.) Under Irrıgation at Selekleka, Northern Ethıopia. - M.Sc. Thesis, 111 Pages. February 2017, Haramaya Unıversity, Haramaya.

[32] Liebig, M. A., Doran, J. W. (1999): Impact of organic production practices on soil quality indicators. - J. Environ. Qual. 28: 1601-1609.

[33] Lim, T. K. (2015): Edible Medicinal and Non-Medicinal Plants. - Volume 9. Springer; Dordrecht, the Netherlands: 2015. Modified Stems, Roots, Bulbs; pp. 124-203.

[34] Liu, X., Guangxi, R., Yan, S. (2011): The effect of organic manure and chemical fertilizer on growth and development of Stevia rebaudiana Bertoni. - Energy Procedia 5: 1200-1204.

[35] Mahala, P., Chaudhary, M. R., Garhwal, O. P. (2018): Yield and quality of rabi onion (allium cepa 1.) influenced by integrated nutrient management. - Int. J. Curr. Microbiol. App. Sci. 7(5): 3313-3321. 
[36] Marrelli, M., Amodeo, V., Statti, G., Conforti, F. (2019): Biological Properties and Bioactive Components of Allium cepa L.: Focus on Potential Benefits in the Treatment of Obesity and Related Comorbidities. - Molecules 24(1): 119.

[37] Mekonnen, D. A., Mihretu, F. G., Woldetsadi, K. (2017): Farmyard manure and intra-row spacing on yield and yield components of adama red onion (Allium cepa L.) cultivar under irrigation in gewane district, Afar Region, Ethiopia. - J. Hortic. For. 9(5): 40-48.

[38] Metwally, S. M., Abdel-Bary, E. A. (1999): Assessment of application of amendments to sandy soils using a computer model. - Zagazig J Agric Res 2: 947-962.

[39] Naeem, M., Iqbal, J., Bakhsh, M. A. A. (2006): Comparative study of inorganic fertilizers and organic manures on yield and yield components of mung bean (Vignaradiate L.). Journal of Agriculture and Social Science 2: 227-229.

[40] Nasreen, S., Haque, M. M., Hossain, M. A., Farid, A. T. M. (2007): Nutrient uptake and yield of onion as influenced by nitrogen and Sulphur fertilization. - Bangladesh Journal of Agricultural Research 32(3): 413-420.

[41] Olsen, S. R., Cole, C. V., Watanbe, F. S., Dean, L. A. (1954): Estimation of available phosphorus in soils by extraction with sodium bicarbonate. - USDA Cir. No. 939.

[42] Piazza, C., Reggiani, R., Cera, M. C. (2003): Varietal experiments on organically grown onions. - Sementi Elette 49: 39-41.

[43] Ramesh, P., Singh, M., Rao, S. A. (2005): Organic Farming: It's Relevance to the Indian Contex. - Current Science 88(4): 561-568.

[44] Reuterberg, E., Kremkus, F. (1951): Bestimmung von gesamthumus und alkalischen humusstoffen im boden, z. pflanzenernaehr. Düng. und Bodenkd. - Verlag Chemie GmbH, Weinheim.

[45] Rumpel, J. (1998): Effect of long-term organic, mineral, and combined organic-mineral fertilization on yield of onions (Allium cepa L.) grown from seeds. - Biuletyn Warzywniczy 48: 5-15.

[46] Russo, V. M. (2005): Organic vegetable transplant production. - HortScience 40: 623-628.

[47] Sezen, Y. (1995): Soil chemistry Edition of Ataturk University No: 790. - Atatürk Univ. Faculty of Agriculture. No: 322. Series of Lesson Book. 71. Erzurum.

[48] Shah, S. T., Sajid, M., Alam, R., Rab, A., Mateen, A., Jan, I., Ali, A., Wahid, F. (2012): Comparative study of onion cultivars at Mardan, Khyber Pakhtunkhwa - Pakistan. - Sarhad J Agric 28(3): 399-402.

[49] Shaheen, A., Fatma, M., Rizk, A., Singer, S. M. (2007): Growing onion plants without chemical fertilization. - Res. J. Agr. Biol. Sci. 3(2): 95-104.

[50] Sharma, R. P., Datt, N., Sharma, P. K. (2003): Combined application of nitrogen, phosphorus, potassium and farmyard manure in onion under high hills, Dry temperate conditions of North-Western Himalayas. - Indian J. Agr. Sci. 73(4): 225-227.

[51] Sharma, R. P., Pathak, S. K., Haque, M., Raman, K. R. (2004): Diversification of traditional rice (Oryza sativa)-based cropping system for sustainable production in South Bihar alluvial plains. - Indian J. Agron. 49: 218-222.

[52] Snyman, H. G., Jong, D. E., Aveling, T. A. S. (1998): The stabilization of sewage sludge applied to agricultural land and the effects on maize seedlings. - Water Sci. Technol. 38(2): 87-95.

[53] Soleymani, A., Shahrajabian, M. H. (2012): Effects of different levels of nitrogen on yield and nitrate content of four spring onion genotypes. - Inter. J. of Agric. and Crop Sci. 4(4): 179-182.

[54] Suresh, K. D., Sneh, G., Krishn, K. K., Mool, C. M. (2004): Microbial biomass carbon and microbial activities of soils receiving chemical fertilizers and organic amendments. Archives Agronomy Soil Science 50: 641-647.

[55] Velmurugan, A., Swarnam, P. (2017): Nutrient uptake and residual effect of organic treatments applied to vegetable-rice system in an acid soil. - Journal of Plant Nutrition 40(12): 1755-1772.

[56] Ware, M. (2017): https://www.medicalnewstoday.com/articles/276714.php. (2019). 
[57] Whitmore, A. P. (2007): Determination of the mineralization of nitrogen from composted chicken manure as affected by temperature. - Nutr. Cycl. Agroecosyst. 77: 225-232.

[58] Yassen, A. A., Khalid, Kh. A. (2009): Influence of organic fertilizers on the yield, essential oil and mineral content of onion. - Int. Agrophysics 23(2): 183-188.

[59] Yi, D., Cao, W., Xiao, G. (2004): Effect of Balanced Fertilization to Potato in High Altitude Areas of Guizhou Province. - Chinese Journal of Soil Science 35(1): 48-51.

[60] Yohannes, K. W., Belew, D., Debela, A. (2013): Effect of farmyard manure and nitrogen fertilizer rates on growth, yield and yield components of onion (Allium cepa L.) at Jimma, Southwest Ethiopia. - Asian Journal of Plant Sciences 12(6-8): 228-234.

[61] Yoldas, F., Ceylan, S., Mordogan, N., Esetlili, B. C. (2011): Effect of organic and inorganic fertilizers on yield and mineral content of onion (Allium cepa L.). - African J. of Biotech. 10(55): 11488-11492.

[62] Zewde, A., Mulatu, A., Astatkie, T. (2018): Inorganic and organic liquid fertilizer effects on growth and yield of onion. - International Journal of Vegetable Science 24(6): 567-573. 